\title{
A Contemporary History of Bullying \& Violence in South Korean Schools
}

\author{
Trent M. Bax ${ }^{1}$ \\ ${ }^{1}$ Sociology Department, Ewha Womans University, Seoul, South Korea \\ Correspondance: Trent M. Bax, Sociology Department, Ewha Womans University, Seoul, South Korea. Tel: \\ 82-3277-2246. E-mail: trentbax@hotmail.com
}

Received: May 26, 2016 Accepted: June 12, 2016 Online Published: June 21, 2016

doi:10.5539/ach.v8n2p91 URL: http://dx.doi.org/10.5539/ach.v8n2p91

\begin{abstract}
At the end of 2011 a bully-suicide case set off a wave of public and political concern for and increased sensitivity toward bullying-and-violence in South Korean schools. Following yet another high-profile bully-suicide case in 2013 the issue of school violence was designated a 'social evil,' with punitive-leaning and security-centric measures quickly implemented to try and 'eradicate' bullying-and-violence from South Korean society. During this period a particular discourse emerged - seemingly supported by survey data - claiming violence in schools in recent years has: a) become more pervasive, b) is occurring earlier and, c) like 'gangsters,' violent students are becoming more 'organized.' This paper critically analyzes this discourse by offering a 'history of the present' of school violence in South Korea from the 1950s until the present. Historical, empirical, developmental and international data are used to more accurately situate student-initiated violence, and, at the same time, to call in to question the current perceptions of juvenile delinquency and of juvenile justice.
\end{abstract}

Keywords: South Korea, bullying, school violence, history, iljin, wang-tta

\section{Introduction}

This paper provides a timely, yet critical, review of the socio-political developments of school bullying-and-violence in South Korea from the 1950s until the present. This 'history of the present' begins with the bully-suicide of a 13 year-old student, as his untimely death at the end of 2011 can be understood as the 'initial spark' which ignited the current concern for, and increased sensitivity toward, bullying-and-violence in South Korean schools. Then, in March of 2013, the bully-suicide of a high school student functioned as an 'explosion' that ripped through the halls of political power. This resulted in 'school violence' - a misleading term as the 'deep roots' of the bullying-and-violence perpetrated in schools both precede-and-exceed the school gates - becoming one of four 'social evils' the government promised to quickly 'eradicate' from South Korean society; with security-and-school-centric measures the preferred method of state-directed resistance. During this heightened environment a particular discourse emerged - seemingly supported by survey data - claiming in recent years violence in schools has:

- $\quad$ Become more pervasive,

- Is occurring earlier and,

- $\quad$ Like 'gangsters,' violent students are becoming more 'organized.'

This paper critically analyses this discourse with reference to historical material and empirical data. After outlining the methodology, the paper firstly examines the definitional issues underpinning the terms 'bullying' and 'school violence.' In particular, it is argued more attention should be paid to the issue of the power, or more specifically 'dominance-and-submission' that lies at the heart of bullying. Next, the paper addresses the massive variation in the 'prevalence' of bullying found in the literature, which appears more an effect of definitional and methodological inconsistency than rapidly changing socio-cultural conditions. In particular, it is noted the way 'defining bullying up' can both distort reality and misinform. The main body of the paper then begins with the present, wherein both the emergence of the current discourse on school violence and the state's subsequent 'school-and-security-centric' response are examined. This particular discourse is then critiqued by a decade-by-decade discussion of the way school violence-related issues have been presented by the media and perceived by the public. Contrary to populist perception, violence in South Korean schools is far from a recent 
societal problem. In practice and discourse, it has been a recurrent social issue since the mid-1950s; an issue that makes sense if framed within a developmental perspective. The paper concludes by returning back to the present, wherein it is argued that due to misperceptions about the prevalence and nature of school violence we have seen a disjunction appear between, on the one hand, the idea of what juvenile delinquency and the juvenile delinquent is and, on the other, the kinds of juvenile justice policies that have been advocated to try and deal with this perennial social issue. Specifically, the argument is put forward that such policies are not centred on addressing the developmental handicaps facing juvenile delinquents.

\section{Method}

The line of inquiry pursued in this paper is part of a larger developmental case-based study of bullying-and-violence in South Korean society the author has been undertaking (see Bax, in press). While the present paper is narrowly focused upon the modern historical and discursive developments of school bullying-and-violence, the reader is briefly directed to the main method and findings of this larger project as this data both informs and underpins the argument presented here.

This ongoing research is based on the case-file material of perpetrators of school violence, aged 14-18, who have been sent to a Juvenile Detention Centre for a month of 'classification and examination.' Future publications will demonstrate that when we analyse all aspects of their lives we discover that their developmental life-course mirrors that found by developmental-based research conducted internationally. In particular, the Gluecks' (1952) pioneering research into the 'making' of a juvenile delinquent, the ground-breaking longitudinal 'Cambridge Study in Delinquent Development' (West \& Farrington, 1973), and Patterson's widely replicated social-interactional theory that sees 'coercive family processes' as 'training' children to learn and perform antisocial behaviours (Patterson \& Dishion, 1985).

To briefly summarise the case-file material (as compiled by their classification officer), these perpetrators of school violence have experienced high levels of divorce, absence, neglect, punishment, authoritarian violence and inconsistent parenting. This means these 'bully-victims' were victims (at home) before, and while, they were perpetrators (at school). In short, they have experienced a lack of affection, supervision, support and guidance as they grew up in a world where disruption and instability rules over cohesion and stability (Glueck \& Glueck, 1952). The 'exemplary' case of 'Ji-sung' may be presented to demonstrate the relation between family functioning and their bullying-and-violent conduct; what Robert Bly (1996) described as "the rage of the unparented" (Maté, 2000):

In December of 2010, 'Ji-sung' was sent to the Detention Centre after he and his eleven fellow 'iljin' members, going under the name 'Dickhead,' assaulted three of their juniors after catching them smoking. Ji-sung and his friends, on three separate occasions, hit and kicked their juniors about the body over a 90 minute period. They also repeatedly extorted from them a total of 325,000 won (approximately US\$300). In addition, Ji-sung asked one of his juniors if he could 'borrow' his bag, which he did not return. On five occasions he extorted 300,000 won from this same junior, twice hitting him. In May of 2012, Ji-sung was sent back to the Centre after he and two friends were charged with four incidents of threatening behaviour and assault causing harm. According to Ji-sung's classification officer, the 'deep roots' of his delinquent conduct can be traced back to the chronic stressors he encountered within the family. When Ji-sung was one his mother 'ran away,' whereupon he lived with his grandparents until he started attending middle school. Then he began living (in discord and conflict) with his father and step-mother, whereupon his delinquency began. Lack of affection and family support was said to have made him eager to be noticed and accepted by others. His classification officer also believed he got involved with others in delinquency as a way to fill up emotional feelings of emptiness and loneliness. In addition, the father's neglectful yet punitive parenting, coupled with the permissive form of parenting from his (recently deceased yet beloved) grandmother, meant he did not properly form the appropriate moral concepts and stable habits to help guide his behaviour. Yet the stress and conflict arising out of the discordant relations with his father and step-mother was said to have made him 'hyperactive' and angry. He subsequently had trouble controlling this anger, which found an outlet in the form of his juniors. Because of continual conflicts he felt he could not stay at home, which caused his circumstances to worsen as he tried to get by living on the street with his fellow delinquent peers. The extortion was therefore partly motivated by him having insufficient allowance, which he used at internet cafes and for buying cigarettes. 


\subsection{History of the Present}

As far as the method presented in this paper is concerned, the author draws - modestly - from the 'genealogical method' practiced by the French historian, Michel Foucault. While Foucault himself did not clearly define his earlier 'archaeological method' (now understood as an excavation of the archives to analyse systems of knowledge) nor his later genealogical method, he did characterize his research projects as one of writing "the history of the present" (Foucault, 1997). Here the aim of genealogy is a deconstruction of 'truth' and an analysis of 'discourse' (the material traces left behind by a particular historical period and culture) in order to produce knowledge that informs us about the character of contemporary conditions (Foucault, 1972). With concern for diagnosing and critiquing the present, the genealogical method seeks to investigate (in an empirical, interpretive and dialectical way) the relationship between knowledge, power, truth and the human subject in modern society. In particular, a genealogical approach attempts to analyse the way in which conventional interpretations emerge from the contingent (and not linear) turns of history and the influence that a matrix of power has on (the production of) 'truth' (Dreyfus \& Rabinow, 1982).

\section{Discussion}

It was the bully-suicide of 13 year-old middle school student, Kwon Seung-min, on December 20, 2011, that can be understood as the 'initial spark' that ignited the current wave of attention and scrutiny that, in a binary fashion, has pitted violent bullying students ('iljin') against victims ('wang-tta'). Particular attention was directed upon the suicide note Seung-min wrote prior to jumping from his $7^{\text {th }}$ floor family apartment, for it detailed the acts of bullying-and-violence he was subjected to. Seung-min's suicide - the first of many to follow - set in motion a (temporary) process of national collective soul-searching to try and fathom how and why young people could do such cruel and violent things to each other.

Seung-min's bullying victimization can be seen in the way he was (sadistically) subjected to water torture, in the way they attempted to set his arm on fire, in how they used an electrical cable as a dog-collar to drag him around, ordering him to eat food off the floor (like a dog). ${ }^{1}$ He was also beaten both at school and at home when his parents were at work. Not content to merely extort money from him they also ordered him to obtain a part-time job - while, at the same time, making him work as their 'gaming servant.' They also sought to deny him an education by trying to manipulate his exam results and by destroying his textbooks. In addition to the verbal, emotional and physical aggression, one of the boys sent five-to-six threatening messages per day to his mobile phone (Koo 2011). During sentencing, the Court Judge concluded that the harassment and insults inflicted upon Seung-min - who the Judge noted was "relatively weaker' than them - both "destroyed his everyday life" and "devastated his spirit" (Yonhap, 2012).

\subsection{Bullying - Power, Domination \& Submission}

When introducing research on bullying it is customary, almost standard, for academic papers to firstly state bullying is a serious and 'pervasive' social problem throughout the world (Hong, Lee, Lee, Lee, \& Garbarino, 2014), then to explain how prevalent it is and thereafter to briefly highlight the commonly observed effects and consequences suffered by people like Seung-min (Juvonen, Graham \& Schuster, 2003). When we observe the prevalence and outcomes of bullying we discover that prevalence rates vary widely (see below), while the outcomes show wide yet more consistent variance. There is widespread consensus that victims of bullying can potentially suffer from various emotional, psychological and educational problems (Rigby \& Slee, 1999). And beginning with Olweus' pioneering research (1993), it has been found across culturally diverse settings that involvement in school bullying increases the likelihood of subsequent juvenile delinquency and/or adult criminal behaviour (Nansel, Craig, Overpeck, Saluja, \& Raun, 2004; Salmon, James, Cassidy, \& Javaloyes, 2000). Farrington (1991), for example, found that children who bully are more likely to engage in antisocial conduct and/or commit adult criminal behaviour. Conversely, a study of South Korean primary school girls found that bullying victimization caused anxiety in the girls, who responded with defensive, aggressive, and delinquent behaviours (Yang, Kim, Kim, Shin, \& Yoon, 2006). Such research findings speak to an 'unresolved debate' in the literature around the direction of the relationship between school bullying and 'psychopathologic' behaviour. In trying to untangle which is the 'cause' and which is the 'effect,' two opposed positions have been proposed:

1) Pre-existing psychopathologic behaviour is a cause of subsequent bullying.

2) Bullying leads to future psychopathologic behaviours (Kim et al., 2006).

\footnotetext{
1 Suicide note retrieved from: http://blog.naver.com/juwon6320?Redirect=Log\&logNo=150127488530
} 
Simply put, do troubled children cause bullying or does involvement in bullying cause children to become troubled? Research findings in support of both directions have been proffered (Boulton \& Smith, 1994; Hodges \& Perry, 1999; Olweus, 1994; Ladd \& Troop-Gordon, 2003). Yet as the contingent 'dynamic interplay' developmental-based approaches such as the Gluecks' (1952) demonstrate, the debate remains unresolved because school bullying may be considered both a cause and consequence of problematic behaviour.

When the concept 'bullying' is employed we must recognize that while most researchers are in agreement that bullying is a common (even universal) problem, there is no universal agreement on a singular definition (Ross, 2002). Nevertheless, there is widespread agreement that we can define an act as constituting 'bullying' if it includes:

- Physical, verbal, or psychological attack or intimidation that is intended to cause distress, fear, or

- harm to the victim;

- An imbalance of power, with a more powerful person oppressing a less powerful one;

- Absence of provocation by the victim;

- Repeated incidents between the same people over a prolonged period of time (Farrington, 1993)

- (bold added).

Seung-min, we may conclude, was bullied to the full extent of this definition. Drawing from these elements, yet lacking an 'imbalance of power' and 'defenceless on the part of the victim,' the South Korean government's official legal term for 'school bullying' is:

Any form of constant or repeated actions whereby at least two students inflict physical or emotional harm on a specific student or a specific group of students inside or outside of school premises, and then inflict pain thereon (Statutes of the Republic of Korea, 2014).

As to why 'at least two students' need to be involved to meet the definition reflects the fact that putting forth a universally accepted definition of bullying encounters resistance when culturally and socially specific environments are factored in. In Japan, where the nature of bullying has historical and cultural parallels with South Korea, bullying is said to involve more psychological intimidation/harassment than physical violence (Naito \& Gielen, 2005; Hilton, Anngela-Cole \& Wakita, 2010). In South Korea, bullying has been conceptualized as collective ostracism, social exclusion (jipdan ttadollim) and/or peer harassment (gipdan-gorophim) (Ahn, 2002; Lee, 2006). Thus one study found that only a comparatively small proportion of students had been victimized by one student only, with over half of victims claiming they were bullied by 3-5 students and over a quarter by 10 students (Koo, Kwak \& Smith, 2008). This finding was seen in contrast to studies from Western societies, which report a higher proportion of one-one-one/two-on-one bullying (see Nansel et al., 2004, cited below).

But while bullying is essentially understood as 'a systematic abuse of power' (Smith \& Sharp, 1994), what is not asked often enough is: What is 'power'? For Erich Fromm (1947), one of the most influential psychoanalysts of the 20th century, the word 'power' denotes two contradictory concepts:

1. Power of (the 'capacity' to do something), and

2. Power over ('domination' over people, animals, and things).

Power of is understood as the human capacity for 'productiveness' and can be regarded as our life-generating potency. And so through the power of reason we can pierce the surface of phenomena and grasp their essence. Through the power of love we can wear down the wall which separates one person from another. And through the power of imagination we can visualize things that do not yet exist, making us capable of planning, creating and executing.

Power over, by contrast, results from the perversion of this productive power. Where the potency of 'power of' is lacking, our relatedness to the world is perverted into a non-productive "desire to dominate, to exert power over others as though they were things" (Fromm, 1947). In research on the 'prevalence' of school bullying among middle school students in South Korea, who, we should add, live in a society infused with hierarchical structures, authoritarianism and inequality, bullying was said to be perpetrated by students who "seem to have and try to maintain dominance over others" (Kim, Koh, \& Leventhal, 2004). The intention of the bullying was said to "cause mental and/or physical pain to another person" (ibid). Yet at a deeper psychodynamic level, this desire to dominate may be motivated by what Fromm terms the sadistic drive, which in its strongest form he defines as: 
The drive for complete and absolute control over a living being, animal or man [sic] (1964:87).

As experienced by Seung-min, having mastery over another person means transforming that individual into a 'thing' by making them an object of your will so that you can do with them as you please; including hurting, humiliating and enslaving them. In South Korea, this (turning humans into things) phenomenon can be seen in the way bullying students seek mastery over 'weaker' students by turning them into a 'shuttle.' Such shuttles can take various forms, including:

- 'Bread Shuttle,' being forced to do errands for his/her 'master(s),' such as buying bread or snacks.

- 'Bag Shuttle,' being forced to carry the bullying students' belongings.

- 'Homework Shuttle,' being forced to do the bullying students' homework.

- 'Facebook Shuttle,' being forced to push the 'like' button to content the bullying student posts so as to increase his/her/their popularity.

- 'Kakao Story Shuttle,' being forced to both 'like' the content the bullying student(s) has put on their personal Kakao Story page and being coerced into leaving positive comments to posts.

- 'Data Shuttle,' being forced to supply the bullying student(s) with their own smartphone data.

Through this form of domination the 'enslaved' person loses one essential quality of life - their freedom. The most radical aim of this 'sadistic drive' is to make another person suffer, for as Fromm (1964) puts it,

There is no greater power over another person than forcing him to undergo suffering without his being able to defend himself.

But this person is striving for power over others precisely because he/she lacks the power to be. Domination may allow an individual to force another to serve him/her, but in the process it increasingly paralyses his/her own existential need to be productive. Fromm (1973) argues sadism is much more frequently found among frustrated individuals and social classes who feel powerless and gain little pleasure from life. As a body of literature has found, socioeconomic disadvantage is one of the strongest predictors of violent and serious juvenile delinquency (Lipsey \& Derzon, 1998); including in South Korea (Han, 2011). Likewise, in trying to explain South Korea's stubbornly high youth suicide rate, one human rights researcher described the lives of South Korean children and adolescents as "stressed, depressed and deprived of freedom" (Oh, 2014).

Whether one agrees or not with Fromm's psychoanalytic interpretation is less important than recognizing this distinction between power of and power over, as it helps us understand the 'dominance-submission' cycle at the heart of bullying. Fromm argued that the human capacity for cruelty and destructiveness cannot simply be understood as the product of some innate aggressive instinctual trait found in human nature. Rather, our human, all too human, 'malignant-destructive aggression' is largely the product of 'civilization' - beginning with the 'urban revolution' that first began in Egypt around 3000BC and which slowly, and unevenly, led to urban, class-based, patriarchal, specialized and hierarchical societies (as found in South Korea) (Fromm, 1973). More recently, this view has found partial expression in the theory of 'social dominance' as an explanation for the universality of peer aggression (Sidanius \& Pratto, 1999). Individually, it is when adolescents lack productive potency - due to their non-productive and dysfunctional developmental circumstances - that they are more likely to turn from 'living productively' to desiring domination and exerting power over others as though they were 'things' (Farrington, 2010). We must therefore ask: Do 'school-and-security-centric' policies and measures address these deeper developmental and civilizational causal factors?

Unfortunately, the key elements that constitute 'bullying' - i.e., attack/intimidation; power imbalance; unprovoked \& repeated action - are not always properly and consistently defined. The massive variation in the 'prevalence' of bullying is partly attributed to this inconsistency. In South Korea, rates can vary anywhere between $0.25 \%$ (Kim, 2013) and 49.2\% (Yi, 2013), and in the international data anywhere from $0.7 \%$ (Farrington, 1993) to 76\% (O'Moore \& Hillery, 1989). If researchers ask students to self-report whether they have 'ever' been bullied the prevalence is often quite high (but since this does not capture repeated abuse then is it 'bullying'?) (ibid). Conversely, if the frequency is more strictly defined the prevalence rate reduces considerably. A study of 25 Western nations, for example, concluded that, on average, $11 \%$ of students were victims and 10\% were bullies 'two or more times' during the current school term (Nansel et al., 2004). And if the frequency is even more strictly defined, such as being bullied 'once a week or more often,' the prevalence rate reduces even further (usually below 10\%). Research from England, for example, found that $1.7 \%$ of male and $0.7 \%$ of female high school students reported 'frequently' bullying others (Whitney \& Smith, 1991). And in research which sought to review the 'nature and extent' of bullying and victimization in South Korean schools, 
the victimization rate halved - from $5.8 \%$ to $2.9 \%$ - when the time frame decreased from 'within a term' to 'within a month (or shorter)' (Koo et al., 2008).

It has thus been noted that while survey-based research has been useful in raising awareness about important aspects of bullying-and-violence in South Korean schools, such research obscures our understanding because they have yielded such widely varying prevalence rates (ibid). Thus rates of victimization can range anywhere from 2\% (CYP, 2002) to 3.7\% (Supreme Public Prosecutor's Office, 1998) to 6.6\% (Lee \& Kwak, 2000) to $24 \%$ (Park, Son \& Song, 1998) to 30\% (Kim \& Park, 1997) to 41.8\% (Yi, 2013). The massive variation between the rates is generally attributed to the 'differing terms and methodologies used' (Moon, Morash \& McCluskey, 2012); and not, importantly, to rapidly changing socio-cultural conditions. Consequently, research indicating high rates of bullying and victimization - which tends to signify that the definition has been widen to include some acts as 'bullying' that should not be defined as such - can then be used to demonstrate its (seemingly increasing) pervasiveness. The effect of 'defining bullying up' is that reality gets distorted and the public and politicians get misinformed.

\subsection{Bullying Becomes Rampant}

Seung-min's grieving mother hoped her son would be "the last victim of bullying at school" (Yim, 2011). Yet 10 days later a female middle school student in Seung-min's home city of Daegu jumped to her death from an apartment building (Kim, 2011). And by October of 2012, during which time the government had launched a large-scale 'crack down' on school violence, there had been 13 bullying-related attempted suicides in Daegu alone (Chung \& Song, 2012). Of the 13 suicide attempts, four of them had taken place in Suseong, a district known to be 'highly competitive' among students and their parents. "I wish my parents and teachers," a middle school student told reporters, "would lower their expectations a little about grades" (ibid).

"We are really sorry," Seung-min's perpetrators professed after being apprehended (Koo, 2011). But considering the nature of the (sadistic) violence they inflicted upon Seung-min, they unexpectedly qualified this regret by adding: "We didn't know things we did in fun would end up like this" (ibid). Yet these boys are far from alone in morally neutralizing their bullying behaviour in this way. One survey of 7,000 fourth-to-sixth graders at 21 elementary schools found that $29.3 \%$ of those admitting to have 'used violence' claimed to have done it 'just for fun' (Kwon, 2012). While four male students were identified as being involved in behaviour the police called "worse than that of gangsters" (Yim, 2011), only the two identified in Seung-min's suicide note, both 15 year-olds, were prosecuted. In sentencing, the Judge declared that "given the dire reality of rampant school violence," and the boy's 'reprehensible' actions, then prison sentences were 'inevitable' (Yonhap, 2012).

Throughout 2012-2013, school bullying-and-violence (suddenly) came to be perceived as 'rampant' partly because the public were reading survey results that seemed to confirm the Judge's perception. Two days after Seung-min's perpetrators were sentenced, an article appeared about a 16 year-old student who was buried up to his neck and then urinated on by his (sadistic) 'friends' a police officer labelled "cruel, cold-blooded gangsters" (Na, 2012). Investigators later discovered, however, that the perpetrators were previously harassed and 'tortured' by their seniors, thus demonstrating how prior victimization provides 'bully-victims' with some kind of cyclic 'fuel' for their sadistic (dominance-submission-based) behaviour. As research has discovered (Unnever, 2005), such 'bully-victims' tend to not only be more troubled than 'pure bullies' but also tend to bully more severely and are more likely to commit major acts of violence against other kids. Nevertheless, this article contained the results of a survey of 3,500 elementary, middle and high school students which found $22 \%$ of respondents reported being 'attacked or bullied by their peers in the past year.' And of these almost half (45.9\%) said they kept the experience a secret (Na, 2012).

Then in October of 2012 a survey appeared in an article titled ' $30 \%$ of children used violence against colleagues at school: survey' (Kwon, 2012). Again, almost half (46.4\%) said they did not call for help from either teachers or parents. But like most aspects of school bullying-and-violence in South Korea, these relatively low rates of reporting victimization accords with the international data, which shows a widespread moral censure among students against 'telling tales' and a widespread fear of revenge (Mellor, 1990).

At the start of 2013, appearing in an article with the eye-catching headline' $40 \%$ of students suffer from school violence,' a survey of 11,714 students at 98 schools throughout Seoul reported that between June and August of $201241.8 \%$ of students aged between 7-and-18 said they were 'bullied, harassed or physically attacked at least once' in 2012; while $49.2 \%$ reported bullying their classmates 'at least once in the last year' (Yi, 2013). Much was made of this rate and the increase from the $27.6 \%$ of students reporting victimization and the $36.9 \%$ reporting bullying behaviour when the same survey was conducted in 2010. The underlying message was that the frequency of bullying had increased since 2010. But since bullying is defined as abuse repeatedly over a period 
of time then including one-off abuse distorts such findings. In addition, $10.2 \%$ said they were 'teased' while $13.2 \%$ said they had teased others, yet, as Jones (1991) has argued, teasing needs to be set apart from 'bullying' behaviour. Yet what was not highlighted was the - more positive - finding that only $9.2 \%$ of the perpetrators said they had 'punched' another classmate, while only $7.1 \%$ of the victims reported to have suffered any kind of 'physical injuries.' Against popular perception, this relatively low rate of physical violence in South Korea has been found in other research (Kim et al., 2004; Koo et al., 2008; Moon et al., 2012).

\subsection{The Explosion}

While Kwon Seung-min was the 'initial spark' that ignited the current concern about school violence-related behaviour, the bully-suicide in March 2013 of a 15 year old high school student, surnamed Choi, can be seen as the 'explosion' which tore into the halls of political power. Choi's bully-suicide sparked widespread public concern and prompted newly-elected President Park Geun-hye to order emergency measures to try and extinguish the flames of school violence (Chu, 2013). Significantly, the issue of school violence was also brought into the centrepiece of the Park Geun-hye administration's criminal justice policy after it was designated - along with 1) domestic violence, 2) sexual violence and 3) food-related crimes - one of four 'social evils' the government promised to quickly 'eradicate' from South Korean society. "Fighting against the 'four social evils' is the most basic direction that the new government pursues for the happiness of the people," President Park declared (ibid).

Since Choi criticized the effectiveness of existing security measures by emphasizing in his suicide note that he was beaten in 'blind spots' outside the vision of 19 surveillance cameras installed at his school, then concern centred on a 'lack of protective measures' at schools. While, at the social level, researchers have developed and implemented various school violence prevention and intervention programs (Hong et al., 2014), President Park subsequently promised, at the political level, to strengthen public security. Punitive-leaning and security-centric measures included proposals to:

- Install more high-tech surveillance cameras at schools,

- Expand the proportion of schools with security personnel,

- Enhance check-ups by police officers at schools,

- Develop anti-bullying education programs (Chu, 2013), and

- Increase punishment for perpetrators (Oh, 2013).

But as a middle school teacher accurately observed:

Most bullies are from dysfunctional families who have been rejected and have deep anger inside. It is not only a matter of school, but also a matter of family and society (Kim, 2013).

In fact a year earlier, following the aftermath of Seung-min's bully-suicide, the Lee Myun-bak administration had enacted a series of similar school-and-security-centric measures, which included:

- Creating a hotline and website offering tips on school bullying,

- Installing more closed-circuit cameras in schools,

- Setting up a school police system to allow police officers to patrol schools,

- Giving principals and teachers greater 'authority' in dealing with violent students (Na, 2012).

Choi's death, one year later, therefore raised questions about the effectiveness of the government's protective measures to successfully stem the (seemingly) rising tide of school violence cases (Oh, 2013).

With school violence now elevated to a 'social evil,' a politician from President Park's ruling Saenuri Party cited government data to declare that school violence is "becoming more serious year by year" (Kim, 2013). The data stated that there were 17,866 'school bullies' in the first semester of 2012; up 32\% from 2011 and 79\% from 2010. This figure was calculated to indicate that 2.5 bullies per 1,000 students had 'initiated violence' in schools between March and July of 2012. Yet when compared to the various findings cited above showing high prevalence rates, here just $0.25 \%$ of students were classified as 'school bullies.' In fact, this is not the only low prevalence rate to have appeared. One example is the recent 'Children's World Survey,' a 15 nation-wide survey that sought to understand "children's evaluations of their life as a whole and specific aspects of their lives" (Rees \& Main, 2015). Despite South Korean 10-and-12 year olds ranking either bottom or fairly low for virtually all questions pertaining to their satisfaction with life, they scored lowest on the measure "being bullied," which included the "frequency of being hit by other children in school in the last month," and the "frequency of being left out by other children in school class in the last month." 
Not only has survey data regularly appeared purporting to show sharp increases in school violence since 2010, but, at the same time, social commentary has framed today's violence in schools as:

- Becoming more 'cruel,'

- Occurring at a younger age, and

- Becoming - like criminal gangs - more 'organized' (Park, 2013).

\subsection{Modern History of Violence in Schools}

Sceptical of the populist perception that violence in schools had suddenly exploded into public consciousness because today's youth had suddenly become more violent and cruel compared to past generations of students (Huw, 2013), a perceptive blogger, writing under the name 'Gordon,' sought to counter this discourse by searching through newspaper archives from the 1950s until the present. ${ }^{1}$ His archaeological excavation reveals that violence in South Korean schools is far from a recent societal problem. In practice, it is as old as school itself and has been a perennial social issue since the end of the inter-Korean War.

\subsubsection{The $1950 \mathrm{~s}$}

Articles are unearthed from the 1950s with titles such as 'School Violence Should be Kicked out from School' (Kyunghyang Shinmun, 1957) and 'The Classroom is Shaking with Fear from Violence' (Dong-A Daily, 1959). They describe vicious fights between large groups of students involving deadly weapons, individual 'gangster' students extorting from, attacking, and even killing other students. And, like today, commentaries elevated school violence to a social-and-moral issue requiring immediate attention, including parents criticising school authorities for trying to cover up the issue for its own benefit.

\subsubsection{The 1960s}

From the 1960s, articles show that after the Park Chung-hee military regime took power Park tried to 'eradicate' school violence using governmental authority and power. This included police creating an 'organisational map' to deal with 'school gangsters' in the same manner with which they dealt with adult organized criminal gangs. One case of 'school gangsters' is highlighted in an article titled "I am Afraid of Going to School," wherein a well-known and reputable high school had, like most if not all schools, a 'violent circle' (Dong-A Daily, 1963). This group of violent students had about 20-30 members who bullied 'good' students. They had also tried to hit a teacher using a stone and had brought bats to school to attack another teacher.

The measures implemented by Park's military regime were designed to 'eradicate' these 'violent circles' from South Korean society. What is striking is that both the Park Chung-hee (1963-1979) and the later Chun Do-hwan (1980-1988) military regimes, along with the Kim Young-sam-led government (1993-1998) (Lee, 1997) and the current Park Geun-hye administration have all used the same word - to 'eradicate' (gun cheol) - in describing their approach to solving the issue of school violence. In a similar vein, the Kim Dae-jung Administration (1998-2003) launched a 'war' on school violence in $2001 .^{2}$ This war rhetoric was partly motivated by a high school 'bully-victim' of school violence vengefully killing his attacker in the city of Busan.

While the 1950s-1960s was characterized by large group fights involving the use of deadly weapons, such student-initiated violence was said to not have generated the kind of widespread public attention seen today because such behaviour was 'drowned out' by larger and more pressing issues such as poverty alleviation, national reconstruction and economic development.

\subsubsection{The $1970 \mathrm{~s}$}

In 1975, 'The Centre for Juvenile Protection Measures' surveyed 13,900 high school students and 1,609 ex-students who were in employment. In findings comparable to current survey data, it was reported that $32.4 \%$ of the high school students reported being 'harmed' by other students, which included violent assault, extortion and/or sexual harassment (Dong-A Daily, 1975). By contrast, only 3.6\% of the juveniles in employment reported being harmed. A case from 1972 demonstrates the potential effects of being harmed, after a male student, who had performed poorly in school, was disliked by the teachers, ignored and bullied by his classmates and faced

\footnotetext{
1 The blog is called 'Caperture Laboratories'. There are 5 blog entries on the history of school violence in South Korea. Blog 1: http://blog.naver.com/jjy0501/100152772193 Blog 2: http://blog.naver.com/jjy0501/100153198591 Blog 3: http://blog.naver.com/jjy0501/100153299538 Blog 4: http://blog.naver.com/jjy0501/100153539548 Blog 5: http://blog.naver.com/jjy0501/100153589147

2 Taken from the following timeline on developments of school violence: http://bbungou.blog.me/10146456135.
} 
indifference from his father and step-mother, tried to burn his school down. As firemen and students were extinguishing the flames, the boy confessed, screaming "It burns really well, I made that fire" (Min, 2010).

While fights between students or the problem of bullying were still covered by the media in the 1970s, due to South Korean society being 'hectic' the problem of school violence did not receive close public scrutiny. With the current government's central socio-economic policies focused on increasing 'happiness' and a 'creative economy' we can see why the issue of school violence would receive greater public and political attention today.

\subsubsection{The $1980 \mathrm{~s}$}

The 1980s, however, saw group bullying and juvenile delinquency come to be seen a pressing societal problem. This was partly due to Japan being in the grip of an 'ijime phenomenon' wherein victims of 'ijime' ('bullying') were committing suicide. Seemingly identical to contemporary South Korea, the Japanese media presented to the public a number of students' suicide notes, which described their anguished cry for help (Naito \& Gielen, 2005). This phenomenon piqued both the interest and fear of South Korean citizens and subsequently led to the creation of the terms 'iljin' (from ijime) and 'wang-tta.' 'Wang' means 'King' or 'best,' while 'tta' means to ostracize/exclude; thus 'wang-tta' has been defined as "the act of singling out one person in a group to bully and ostracize" (Chee, 2006).

An article from the early 1980s titled 'Scary Teenagers are Getting More Cruel' (Lee, 1982) highlights the way students were perceived as becoming increasingly cruel and vicious. This article argued 'scary kids' are spreading in academic institutions like 'toxic mushrooms' resulting in schools becoming a 'very violent' place. Thirty years later we can today read the following phrase 'the kids are scary these days' (Huw, 2013).

Another article from 1982, titled 'The Way to and From School is Scary' (Dong-A Daily), argued that violent cases were getting more 'chronic' as (is universally common) the victims were unwilling to tell teachers and parents due to fear of revenge. It also argued that one 'remarkable characteristic' of school violence and juvenile crime is the 'trend' of youth crime becoming more 'organized,' with students creating a 'circle organization' and acting collectively - like gangsters - to engage in deviance. Seoul reportedly had two or three 'violent circles' present in almost every school. The article describes how such violent circles are formed. With regard to the 'Sub-Station Club,' new members would go through an initiation ritual which entailed slashing their palm with a knife and as blood dripped out they pledged their loyalty to the circle. And to show their power, domination and/or authority, senior members would hit junior members with a baseball bat. They also reportedly carried with them pipes, knives, saws, and hydrochloric acid to threaten or extort from people. Moreover, they sometimes sexually assaulted female students or female factory workers. In another example of a 'violent circle' it was shown - like today's 'iljin' group (Kim \& Kim, 2008) - that circle members all share similar characteristics, including:

- Coming from an economically deprived background,

- Having a poor study record, and

- Having one or both parents missing.

Such personal characteristics are also seen in international studies of bullying, which have established that those who bully tend to be drawn disproportionately from lower socioeconomic-status families with poor child-rearing techniques and who tend to be unsuccessful in school (Farrington, 1993).

Collectively, the news articles in the 1980s followed a similar pattern: the news frames school violence as getting worse and students becoming more cruel and vicious. One article, titled 'Violent Classrooms ... Followed by School Transfer' (Kim, 1986), about the increasing number of students seeking to transfer schools to avoid bullying victimization, claimed that school violence was more severe in elementary and middle schools when compared to high schools (Kim 1986). While the same argument is being made today it is presented as a recent phenomenon. In one 2013 article about the 'knife scar phenomenon,' where, like the 'Sub-Station Club' members above, students deliberately carve knife marks into their wrists to cement their friendship and to share photos of their scarred wrists to their friends through SNS, it was argued that elementary school children are becoming 'endangered' as violence and deviance is spreading from the middle and high school to the lower ages through the internet and SNS (Park, 2013). Data from the 'Adolescent School Violence Prevention Group' is cited to show that the organization's Call Centre had seen an increase in calls from elementary students. Likewise, the Seoul Adolescent Counselling Welfare Centre is quoted as saying that since 2011 the number of students from elementary school seeking counselling had rapidly increased. 


\subsubsection{The $1990 \mathrm{~s}$}

Throughout the 1990s the media also depicted school violence as being on the rise. Newspapers regularly published articles on the increasing 'brutalization' of violence in schools, which by mid-1997 was seen as a 'huge' social issue. This heightened public concern stemmed from a number of incidents that 'shocked the nation,' such as the case of elementary school student who cut out the tongue of his junior classmate. Likewise, in 1996 a third year high school student stabbed a classmate who had bullied him. Such cases led to the establishment in 1997 of the Juvenile Protection Act (Kyunghyang Shinmun, 1996). The journalist of this article was of the opinion that such legalistic measures would not provide a 'fundamental solution' to the problem. This was because the causes of school violence were said to be deeply-rooted in harmful home, school and social environments.

\subsection{Developmental Trajectory of Bullying}

While we have seen, since the 1980s, a recurring discourse that makes it appear that the problem of school violence is getting more severe as it begins to 'infiltrate' previously 'innocent' children, international research tends to show that it is 'normal' for bullying to begin in elementary school (and may be the most violent during this period), then to often 'peak' in prevalence around late middle school and to finally 'taper off' in high school (Pellegrini, 2004). David Farrington (1993), perhaps the world's leading authority on juvenile offending, concludes after reviewing international literature on bullying, that perpetrators and victims are generally less prevalent in secondary schools than in elementary schools. And as shown in research by Olewus (1990), the prevalence of victims tends to steadily decline with age for both males and females.

We see this 'aging out' process in a national study of 'ijime' in Japan from the mid-1990s, which found that 21.9\% of elementary students reported being victims of ijime, which had decreased to $13.2 \%$ for lower-high school students and had dropped to 3.9\% for upper-high school students (Naito \& Gielen, 2005). Likewise in South Korea, it has been argued that bullying peaks between the sixth grade and eight grade and then gradually decreases throughout high school (Lee, 2010). And another study found a steady decrease in prevalence rates with each grade level (Koo et al., 2008).

This trajectory of bullying behaviour makes sense from a developmental perspective. It is said that one of the tasks and challenges of childhood and adolescence is learning and exploring one's behavioural and social capacities and testing out the dynamics of power, authority and deviancy. So elementary school children are more likely to use bullying to establish 'dominance,' but once status is established they may decrease using power aggressively and, as they develop social and moral understanding, increase their use of 'affiliative strategies' (Pepler, Jiang, Craig, \& Connolly, 2008). For those who continue to bully, however, their desire for domination, destruction, power and prestige is rooted not in 'evilness' or even 'powerfulness' but, on the contrary, in their lack of productive potency (i.e., powerlessness) (Fromm, 1964). And from a more historical perspective, South Korean adolescents are coming of age within a hyper-competitive 'winners vs. losers' examination-oriented educational environment. At the same time, they live in a 'senior vs. junior' society where we can observe the stubborn continuity of traditional hierarchical and authoritarian cultural practices. Considering these developmental and ecological factors, should we be surprised that school bullying-and-violence has been such a perennial problem seemingly without end or solution?

\section{Conclusion}

While professionals, politicians and the public should be applauded and supported for seeking to reduce rates of bullying-and-violence in South Korean schools, the current perceptions-and-policies regarding this important task needs to be questioned. This relationship between perception-and-policy can be connected to two ideas:

1) The idea of juvenile delinquency, and

2) The idea of juvenile justice.

According to Bernard \& Kurlychek (2010), the 'idea of juvenile delinquency' can be understood as a general overview of what delinquency is and how it originates. They argue that two (opposed) ideas are generally put forward to explain delinquency. The first view understands delinquency to be committed by self-centred adolescents who, lacking self-control, do not care about the feelings and rights of other people. The second view understands juvenile delinquency as a 'cry for help' from young people who come from abusive and neglectful home environments. Closely connected to this idea of delinquency is the perception of the individual delinquent. In the first view, the delinquent is perceived as more like a hardened criminal - or 'gangster' - than as a child. In the second view, the delinquent is perceived more of as a child than a younger version of a hardened criminal. 
Bernard and Kurlychek argue that these ideas of delinquency and of the delinquent are important because they inform the perception people have of juvenile justice. Those who view the juvenile as like a gangster in an organized crime gang are more likely to advocate punishment, deterrence and security-based policies; which a meta-analysis of intervention measures found to be the least effective (Lipsey, 2009). Conversely, those who view the juvenile as a victim (of maladaptive circumstances) are more likely to favour reform and rehabilitation-based policies that address the juvenile's 'cry for help' (which the above meta-analysis found to be most effective). If the delinquents really are the way they are perceived then the proposed policies should, in theory, be able to work when put into practice. But if the delinquents are actually different from the perception of them then the proposed policies are not likely to work - and may actually worsen the problem of juvenile delinquency.

As 'classification officers' consistently write in their case files of juveniles detained on school violence-related charges, South Korea's juvenile delinquents can be understood as emerging from abusive and neglectful home environments - with around a 'chronic 6\%' becoming 'persistent offenders' (Wolfgang, Figlio, \& Sellin, 1972; Han 2011). Yet as a discourse has emerged that has perceived 'iljin' as being more like 'cruel, cold-blooded gangsters,' and as 'rampant' school violence was elevated to a 'social evil,' then the previous and current governments have sought punishment, protective, deterrent, security and school-centric policies in their attempts to hurriedly 'eradicate' violence from schools. Since such policies are not centred on addressing the developmental handicaps facing juvenile delinquents - unlike several bullying intervention programs that have targeted parenting behaviours and practices (Hong et al., 2014) - then we may ask how such perceptions-and-policies will successfully address the 'deep roots' of bullying-and-violence in South Korean schools?

\section{Acknowledgements}

This research was supported by funding from the National Research Foundation of Korea, 2012-2013. Grant number: 2013S1A5A8023561.

\section{References}

Ahn, H. (2002). A study of the fact that "Ijime" affects "Wangtta." Jechon-Shi, South Korea: Sae-Myung University.

Bax, T. (in press). Bullying and Violence in South Korea: From home to school and beyond. London: Palgrave and Macmillan.

Bernard, T. J., \& Megan, C. K. (2010). The Cycle of Juvenile Justice. New York: Oxford University Press.

Bly, R. (199). The Sibling Society. New York: Vintage Books.

Boulton, M. J., \& Smith, P. K. (1994). Bully/victim problems in middle-school children: stability, self-perceived competence, peer rejection and peer acceptance. British Journal of Developmental Psychology, 12(3), 315-329. http://dx.doi.org/10.1111/j.2044-835X.1994.tb00637.x

Chee, F. (2006). The Games We Play Online and Offline: Making Wang-tta in Korea. Popular Communication, 4(3), 225-239. http://dx.doi.org/10.1207/s15405710pc0403_6

Chu, C. (2013). Teen's death spurs call for action against bullying. The Korea Herald. Retrieved March 14, 2013, from http://nwww.koreaherald.com/view.php?ud=20130313000936

Chung, K. H., \& Song, J. Y. (2012). Daegu teen suicides have striking commonalities. Korea Joongang Daily. Retrieved October 18, 2012, from http://koreajoongangdaily.joins.com/news/article/article.aspx?aid= 2960870

Commission on Youth Protection (CYP). (2002). A study on school violence through the Internet. Youth Protection, 2002-2038.

Dong-A Daily. (1959). The Classroom is Shaking with Fear from Violence. Dong-A Daily. Retrieved July 14, 2014, from http://newslibrary.naver.com/viewer/index.nhn?articleId=1959110600209103001\&editNo= $2 \&$ printCount $==1 \&$ publishDate $=1959-11-06 \&$ officeId $=00020 \&$ page $\mathrm{No}=3 \&$ printNo $=11536 \&$ publish Type $=$ 00010

Dong-A Daily. (1963). I am Afraid of Going to School. Dong-A Daily. Retrieved July 14, 2014, from http://newslibrary.naver.com/viewer/index.nhn?articleId=1963052400209202001\&editNo=2\&printCount= $1 \&$ publishDate $=1963-05-24 \&$ officeld $=00020 \&$ pageNo $=2 \&$ print $N o=12790 \&$ publishType $=00020$ 
Dong-A Daily. (1975). The Centre for Juvenile Protection Measures: Adolescents Avoid Reporting Harm. Dong-A Daily. Retrieved July 15, 2014, from http://newslibrary.naver.com/viewer/index.nhn?articleId= $1975011600209207001 \&$ editNo=2\&printCount $=1$ \&publishDate $=1975-01-16 \&$ officeId $=00020 \&$ pageNo=7 $\&$ print $\mathrm{No}=16397 \&$ publishType $=00020$

Dong-A Daily. (1982). The Way To and From School is Scary. Dong-A Daily. Retrieved July 16, 2014, from http://newslibrary.naver.com/viewer/index.nhn?articleId=1982021600209211001\&editNo=2\&printCount= $1 \&$ publishDate $=1982-02-16 \&$ officeId $=00020 \&$ page $\mathrm{No}=11 \&$ print $\mathrm{No}=18575 \&$ publishType $=00020$

Dreyfus, H. L., \& Rabinow, P. (1982). Michel Foucault: Beyond Structuralism and Hermeneutics. Sussex: The Harvester Press Ltd.

Erich, F. (1964). The Heart of Man: Its Genius for Good and Evil. New York: Harper \& Row.

Erich, F. (1973). The Anatomy of Human Destructiveness. New York: Holt Paperbacks.

Farrington, D. P. (1991). Childhood aggression and adult violence: Early precursors and later-life outcomes. In D. J. Pepler \& K. H. Rubin (Eds.), The development and treatment of childhood aggression (pp. 5-30). Hillsdale, NJ: Lawrence Erlbaum.

Farrington, D. P. (1993). Understanding and Preventing Bullying. Crime and Justice, 17, 381-458. http://dx.doi.org/10.1086/449217

Farrington, D. P. (2010). Family influences on delinquency. In D. W. Springer, \& A. R. Roberts (Eds.), Juvenile Justice and Delinquency (pp. 203-222). Sudbury, Mass.: Jones and Bartlett.

Foucault, M. (1997). The Essential Works of Foucault: Ethics, Subjectivity and Truth.In P. Rabinow (Ed.), Vol. 1. London: Penguin Books.

Foucault, Michel. (1972). The Archaeology of Knowledge. Translated by. A. M. Sheridan Smith. London: Tavistock

Fromm, E. (1947). Man For Himself: An inquiry into the psychology of ethics. New York: Holt, Rinehart and Winston.

Glueck, S., \& Eleanor, G. (1952). Delinquents in the Making. Paths to Prevention. New York: Harper \& Brothers Publishers.

Han, Y. S. (2011). Research for Desistance of Juvenile Delinquents. Ph.D Dissertation, Graduate School of Dongkuk University.

Hilton, J. M., Linda, A. C., \& Juri, W. (2010). A Cross-Cultural Comparison of Factors Associated With School Bullying in Japan and the United States. The Family Journal: Counseling and Therapy for Couples and Families, 18(4), 413-422. http://dx.doi.org/10.1177/1066480710372919

Hodges, E. V., \& Perry, D. G. (1999). Personal and interpersonal antecedents and consequences of victimization by Peers. Journal of Personality and Social Psychology, 76(4), 677-685. http://dx.doi.org/10.1037/0022 -3514.76.4.677

Hong, J. S., Lee, C. H., Lee, J., Lee, N. Y., \& Garbarino, J. (2014). A Review of Bullying Prevention and Intervention in South Korean Schools: An Application of the Social-Ecological Framework. Child Psychiatry and Human Development, 45(4), 433-442. http://dx.doi.org/10.1007/s10578-013-0413-7

Huw. (2013). Jealous Over a Girl, Students Beat Boy to Death. Korea Bang. Retrieved September 14, 2013, from http://www.koreabang.com/2013/videos/jealous-over-a-girl-students-beat-boy-to-death.html

Jones, E. (1991). Practical Considerations in Dealing with Bullying in Secondary School. In Elliot, Michele (Ed.), Bullying: A Practical Guide to Coping for Schools (p. 16-17). Harlow: Longman.

Juvonen, J., Graham, S., \& Schuster, M. (2003). Bullying among young adolescents: The strong, the weak, and the troubled. Pediatrics, 112(6), 1231-1237. http://dx.doi.org/10.1542/peds.112.6.1231

Kim, E. H. (2011). Middle school student commits suicide after talking with home room teaching telling her she was a wangtta. $M B C$ News. Retrieved January 3, 2012, from http://news.naver.com/main/read.nhn?mode $=$ LPOD\&mid=tvh\&oid=214\&aid $=0000199392$

Kim, H. S., \& Kim, H. S. (2008). The Impact of Family Violence, Family Functioning, and Parental Partner Dynamics on Korean Juvenile Delinquency. Child Psychiatry \& Human Development, 39(4), 439-453. 
Kim, J. D. (1986). Violent Classrooms ... Followed by School Transfer. Kyunghyang Shinmun. Retrieved July 16, 2014, from http://newslibrary.naver.com/viewer/index.nhn?articleId=198605230032 9211001\&editNo $=2 \&$ printCount $=1 \&$ publishDate $=1986-05-23 \&$ officeId=00032\&pageNo=11\&printNo=12509\&publishType $=00020$

Kim, J. W. (2013). School violence unveils ugly aspects of Korea. The Korea Times. Retrieved March 20, 2013, from http://www.koreatimes.co.kr/www/news/nation/2013/03/180_132285.html

Kim, Y. S., Koh, Y. J., \& Bennett, L. L. (2004). Prevalence of School Bullying in Korean Middle School Students. Archives of Pediatrics and Adolescent Medicine, 158(8), 737-741. http://dx.doi.org/10.1001/ archpedi.158.8.737

Kim, Y. S., Leventhal, B. L., Koh, Y. J., Hubbard, A., \& Boyce, W. T. (2006). School bullying and youth violence: causes or consequences of psychopathologic behavior?. Archives of general psychiatry, 63(9), 1035-1041. http://dx.doi.org/10.1001/archpsyc.63.9.1035

Kim, Y. T., \& Park, H. S. (1997). A survey on bullying among adolescents. Korean Youth Counselling Institute. Youth Counselling Problem Study.

Koo, D. S. (2011). Bullying forces student to take his own life. The Hankyoreh. Retrieved May 20, 2013, from $\mathrm{http} / /$ english.hani.co.kr/arti/english_edition/e_national/511691.html

Koo, H., Kwak, K., \& Smith, P. K. (2008). Victimization in Korean schools: The nature, incidence, and distinctive features of Korean bullying or wang-ta. Journal of School Violence, 7(4), 119-139. http://dx.doi.org/10.1080/15388220801974084

Kwon, D. K. (2012). 30\% of children used violence against colleagues at school: survey. The Korea Times. Retrieved October 15, 2012, from http://www.koreatimes.co.kr/www/news/special/2012/10/139_122182. html

Kyunghyang, S. (1957). School Violence Should be Kicked out from School. Kyunghyang Shinmun. Retrieved July 14, 2014, from http://newslibrary.naver.com/viewer/index.nhn?articleId=1957120500329201004\& editNo $=1 \&$ printCount $=1 \&$ publishDate $=1957-12-05 \&$ officeld $=00032 \&$ pageNo $=1 \&$ printNo $=3814 \&$ publish Type $=00020$

Kyunghyang, S. (1996). School Violence Ends in Murder. Kyunghyang Shinmun. Retrieved July 16, 2014, from http://newslibrary.naver.com/viewer/index.nhn?articleId=1996032000329103007\&editNo=40\&printCount $=1 \&$ publishDate $=1996-03-20 \&$ officeId $=00032 \&$ page $\mathrm{No}=3 \&$ print $\mathrm{No}=15714 \&$ publishType $=00010$

Ladd, G. W., \& Troop-Gordon, W. (2003). The role of chronic peer difficulties in the development of children's psychological adjustment problems. Child Development, 74(5), 1344-1367. http://dx.doi.org/10.1111/ 1467-8624.00611

Lee, C. H. (2010). Personal and Interpersonal Correlates of Bullying Behaviors Among Korean Middle School Students. Journal of Interpersonal Violence, 25(1), 152-76. http://dx.doi.org/10.1177/088626050 8329124

Lee, C., \& Kwak, K. (2000). Bullying at school: Actual condition and characteristics. Seoul: Gipmoondang.

Lee, H. D. (1997). Japan Comics are Textbooks for Violence, the Truth and the Cause of School Violence. Dong-A Daily. Retrieved July 17, 2014, from http://newslibrary.naver.com/viewer/index.nhn? articleId=1997070400209137001\&editNo=45\&printCount=1\&publishDate=1997-07-04\&officeId=000 20\&page $\mathrm{No}=37 \&$ print $\mathrm{No}=23584 \&$ publishType $=00010$

Lee, J. (2006). Collective ostracism among youth in Korea. In C. Daiute, Z. Beykont, C. Higson-Smith, L. Nucci (Eds.), International perspectives on youth conflict and development (p. 124-138). Oxford: Oxford University Press. http://dx.doi.org/10.1093/acprof:oso/9780195178425.003.0008

Lee, J. Y. (1982). Scary Teenagers Are Getting More Cruel. Kyunghyang Shinmun. Retrieved July 16, 2014, from http://newslibrary.naver.com/viewer/index.nhn?articleId=1982030900329203003\&editNo=2\&print Count $=1 \&$ publishDate $=1982-03-09 \&$ office $\mathrm{Id}=00032$ \&pageNo $=3 \&$ printNo $=11213 \&$ publishType $=00020$

Lee, Y. H. (1997). President Kim Orders School Violence to be Eradicated. Mae-il Newspaper. Retrieved July 16, 2014, from http://newslibrary.naver.com/viewer/index.nhn?articleId=1997070900099 102009\&editNo $=15 \&$ printCount $=1 \&$ publishDate $=1997-07-09 \&$ officeId $=00009 \&$ pageNo $=2 \&$ printNo=9801\&publish Type $=$ 00010 
Lipsey, M. W., \& Derzon, J. H. (1998). Predictors of violent or serious delinquency in adolescence and early adulthood: A synthesis of longitudinal research. In R. Loeber, \& D. P. Farrington (Eds.), Serious and Violent Juvenile Offenders: Risk Factors and Successful Interventions (pp. 86-105). Thousand Oaks, CA: Sage

Maté, G. (2000). Scattered: How Attention Deficit Disorder Originates and What You Can Do About It. New York: Plume.

Mellor, A. (1990). Bullying in Scottish Secondary Schools. Edinburgh: Scottish Council for Research in Education.

Min, P. U. (2010). The beginnings of wang-tta and school violence. Naver. Retrieved July 14, 2014, from $\mathrm{http}: / /$ navercast.naver.com/contents.nhn?rid=47\&contents_id=3431

Moon, B., Morash, M., \& McCluskey, J. D. (2012). General Strain Theory and School Bullying An Empirical Test in South Korea. Crime \& Delinquency, 58(6), 827-855. http://dx.doi.org/10.1177/0011128710364809

Na, J. J. (2012). I felt fear of being buried alive. The Korea Times. Retrieved February 23, 2012, from http://www.koreatimes.co.kr/www/news/special/2012/07/181_105463.html

Naito, T., \& Gielen, U. P. (2005). Bullying and Ijime in Japanese schools. In F. L. Denmark, H. H. Krauss, R. W. Wesner, E. Midlarsky, \& U. P. Gielen (Eds.), Violence in schools: Cross-national and cross-cultural perspectives (pp. 169-190). New York: Springer. http://dx.doi.org/10.1007/0-387-28811-2_9

Nansel, T. R., Craig, W., Overpeck, M. D., Saluja, G., \& Raun, J. (2004). Cross-national consistency in the relationship between bullying behaviors and psychosocial adjustment. Archives of Pediatrics and Adolescent Medicine, 158(8), 730-736. http://dx.doi.org/10.1001/archpedi.158.8.730

Oh, K. W. (2013). Seoul to increase security guards, cameras at schools. The Korea Herald. Retrieved March 16, 2013, from http://nwww.koreaherald.com/view.php?ud=20130314000717

Oh, S. Y. (2014). Why Korean Youth Die Young. Human Rights Monitor. Retrieved July 5, 2014, from http://www.humanrightskorea.org/2014/korean-youth-die-young/

Olweus D. (1994). Bullying at school: long-terms outcomes for the victims and an effective school-based intervention program. In L. R. Huesmann (Ed.), Aggressive Behavior: Current Perspectives (p. 97-130). Ann Arbor: University of Michigan. http://dx.doi.org/10.1007/978-1-4757-9116-7_5

Olweus, D. (1993). Bullying at School: What we know and what we can do. Cambridge, MA: Blackwell.

O'Moore, A. M., \& Brendan, H. (1989). Bullying in Dublin Schools. Irish Journal of Psychology, 10(3), 426-441. http://dx.doi.org/10.1080/03033910.1989.10557759

Park, K. S., Son, H. K., \& Song, K. M. (1998). A survey on Gipdan-gorophim (group harassment). Seoul: Korea Institute of Education Development.

Park, S. Y. (2013). 7cm Knife Scar Photos in My 13 Year old Daughter's Kakao Story. Nate News. Retrieved August 14, 2013, from http://m.news.nate.com/view/20130812n02406?f=nate_app\& sform=yes

Patterson, G. P., \& Thomas, J. D. (1985). Contributions of Families and Peers to Delinquency. Criminology, 23(1), 63-79.

Pellegrini, A. (2004). Bullying during the middle school years. In C. E. Sanders \& G. D. Phye (Eds.), Bullying: Implications for the classroom (p. 177-202). New York: Elsevier. http://dx.doi.org/10.1016/b978012617955-2/50014-x

Pepler, D., Jiang, D., Craig, W., \& Connolly, J. (2008). Developmental trajectories of bullying and associated factors. Child development, 79(2), 325-338.

Rees, G. \& Main, G. (Eds.). (2015). Children's views on their lives and well-being in 15 countries: An initial report on the Children's Worlds survey, 2013-14. York, UK: Children's Worlds Project.

Rigby, K., \& Slee, P. T. (1999). Suicidal ideation among adolescent school children, involvement in bully/victim problems and perceived low social support. Suicide and Life-threatening Behavior, 29(2), 119-130.

Ross, D. (2002). Bullying. In J. Sandoval (Ed.), Handbook of crisis counselling, intervention, and prevention in the schools (2nd ed, pp. 105-135). Mahwah, NJ: L. Erlbaum Associates.

Salmon, G., James, A., Cassidy, E. L., \& Javaloyes, M. A. (2000). Bullying a review: Presentation to an adolescent psychiatric service and within a school for emotionally and behaviorally disturbed children. Clinical Child Psychology and Psychiatry, 5(4), 563-579. 
Sidanius, J., \& Pratto, F. (1999). Social dominance: An intergroup theory of social hierarchy and oppression. New York, NY: Cambridge University Press. http://dx.doi.org/10.1017/CBO9781139175043

Smith, P. K., \& Sonia, S. (1994). School bullying: insights and perspectives. London; New York: Routledge.

Statutes of the Republic of Korea. (2014). Act on the Prevention of and Countermeasures Against Violence in Schools. Retrieved October 8, 2014, from http://elaw.klri.re.kr/kor_service/lawView.do?hseq=24031\& lang=ENG

Supreme Public Prosecutor's Office. (1998). Report on school vandalism, Annual Report. Seoul: South Korea.

Unnever, J. D. (2005). Bullies, aggressive victims, and victims: Are they distinct groups? Aggressive Behavior, 31(2), 153-171. http://dx.doi.org/10.1002/ab.20083

West, D. J., \& Farrington, D. P. (1973). Who becomes delinquent? London: Heinemann.

Whitney, I., \& Peter, K. S. (1991). A Survey of the Nature and Extent of Bullying in Junior/Middle and Secondary Schools. Final report to the Gulbenkian Foundation. Sheffield: University of Sheffield.

Wolfgang, M. E., Figlio, R. M., \& Sellin, T. (1972). Delinquency in a Birth Cohort. University of Chicago Press: Chicago.

Yang, S., Kim, J., Kim, S., Shin, I., \& Yoon, J. (2006). Bullying and victimization behaviors in boys and girls at South Korean Primary Schools. Journal of the American Academy of Child \& Adolescent Psychiatry, 45(1). 69-77. http://dx.doi.org/10.1097/01.chi.0000186401.05465.2c

Yi, W. W. (2013). 40\% students suffer from school. The Korea Times. Retrieved January 9, 2013, from http://koreatimes.co.kr/www/news/nation/2013/01/113_128451.html

Yim, S. H. (2011). Student bullied over game commits suicide. Korea Joongang Daily. Retrieved May 27, 2013, from http://koreajoongangdaily.joins.com/news/article/article. aspx?aid=2946117

Yonhap. (2012). 2 teenagers get jail term for bullying friend until suicide. The Korea Times. Retrieved February 21, 2012, from http://www.koreatimes.co.kr/www/news/nation/2013/08/117_105283.html

\section{Copyrights}

Copyright for this article is retained by the author(s), with first publication rights granted to the journal.

This is an open-access article distributed under the terms and conditions of the Creative Commons Attribution license (http://creativecommons.org/licenses/by/3.0/). 